\title{
THE INFLUENCE OF BINAHONG LEAVES (ANREDERA CORDIFOLIA) ON HEALING OF FLOUR ALBUSON FEMALE STUDENTSOF CLASS XI SMAN 1 PACIRAN LAMONGAN DISTRICT
}

\author{
Iswatun ${ }^{1}$, Anestasia Pangestu $\mathrm{MT}^{2}$, Abd Nasir ${ }^{3}$, NazilatulLailiyah ${ }^{4}$ and Arifal \\ Aris ${ }^{5}$ \\ ${ }_{1,2,3}$ DIII Nursing Study Program, Departement of Health, Faculty of Vocational Studies, Universitas \\ Airlangga \\ 4,5 Faculty of Health Universitas Muhammadiyah Lamongan
}

\section{A B S TRACT}

ARTICLE INFO

Introduction: One problem of adolescents at the age of 11-20 years who have not entered adulthood is fluor albus. In the initial survey, more than half of the students (70\%) had vaginal discharge problems. This study aimed to determine the effect of binahong leaves decoction (AnrederaCordifolia) on healing Flour Albuson female Student of class XI SMAN 1 Paciran, Lamongan District.

Methods: The design used pre-experimental method with one grouppre test and post test. The population was all female students who had fluor albus of 34 children and sample of 25 children with consecutive sampling techniques that the inclusion creteria. The data were analyzedusing Wilcoxon Sign Rank Test, with significance level of $p<0.05$ using SPSS V program 22.0.

Results: The results of statistical tests showed that the values of Z: $4.613 b$ and $p=0.000$ where $p<0.05, H 1$ was accepted, meaning that there was an effect of binahong leaves decoction (AnrederaCordifolia) on healing Flour Albus. This study indicated that binahong leaf decoction herbs can reduce and even healing fluor albus with good personal hygiene behavior.
Recived 5 January 2020

Accepted 16 May 2020

Online 29 May 2020

*Correspondence:

Iswatun

*Email:

ibuiswatun@gmail.com

Keywords:

Adolescent, Flluor Albus,

Binahong leaves

\section{INTRODUCTION}

Adolescence is a transition from children to adulthood, not only in a psychological sense but also in a physical sense. This physical change occurs is a primary symptom in adolescent growth, while psychological changes arise as a result of physical changes. The age limit for Indonesian teenagers is 11-24 years and not yet married. The process of adjusting towards maturity has three stages of adolescent development, namely: early adolescence, middle adolescence, late adolescenc (Sarwono,2013). Reproductive health is a state of total physical, mental and social well-being that is not solely free of disease or disability in a relation to the reproductive system, its functions and processes (Prijatni, 2016).

Fluor Albus in adolescents is often found in adolescents who pay less attention to the cleanliness and care of the genetal area. In addition, fluor albus is also often found in adolescents aged 12-14 years where adolescents experience menstruation for the first time (menarche). WHO states that $5 \%$ of adolescents in the world contract sexually transmitted diseases (STDs) with vaginal discharge symptoms each year, even in the United States 1 in 8 adolescents (Notokusumo, 2016).

From WHO data (2012) shows that as many as 276.4 million cases of TrichomonasVaginalis infections occur in women aged 15-49 years, the number of cases of reproductive organ disease (due to bacteria, fungi, parasites and trichomonasvaginalis, vaginal bacterial, syphilis, candida) albicans and gonorrheae) which were treated in 20092011 in the country of Indonesia in the range of 246,448 cases (Ministry of Health RI, 2011). In Indonesia alone, the number of women experiencing fluor albus is very large, more 
than $75 \%$ of women in Indonesia have experienced fluor albus at least once in their lives. More than $70 \%$ of Indonesian women experience fluor albus caused by fungi and parasites such as kermi worms or protozoa (TrichomonasVaginalis).

Based on the initial survey on November 9, 2018 through interviews conducted by researchers at SMAN 1 Paciran, Lamongan District, as many as 10 respondents received 7 (70\%) experiencing pathological fluor albus by mentioning signs and symptoms of pathological fluor albus, among others; in terms of large numbers, yellow, and smelly while $3(30 \%)$ others experienced physiological vaginal discharge by mentioning signs and symptoms of physiological fluor albus, among others; in terms of consistency, the amount is less, the color is like milk, does not smell. So it can be concluded that the high incidence of fluor albus among young women. Indonesia is a tropical country that is always hot all the time. as a result, living in Indonesia automatically makes the body sweat a lot. This condition is what adds to the body's moisture levels, especially in the closed and multiplying sexual and reproductive organs. This condition causes disturbances in the vagina, either in the form of unpleasant odors or infections (Anurogo, 2011). Many factors cause imbalance of the vaginal ecosystem, for example due to oral contraceptives, diabetes mellitus (diabetes), the use of antibiotics, menstrual blood, seminal fluid, the presence of certain fluids spraying into the vagina, and hormonal disorders due to puberty, pregnancy, and menopause (Anurogo, 2011).

Efforts that can be done to cure fluor albus can be with pharmacological and nonpharmacological therapy, pharmacological therapy depends on the cause of infection such as fungi, bacteria or parasites. Generally given drugs to overcome complaints and stop the infection process in accordance with the cause. While non-pharmacological therapy, fluor albus can be reduced by washing the vagina several times a day, namely with betel leaves. The content of the betel leaf contains atrisi oil in which there is phenol which has antiseptic power and contains a distinctive aroma or fragrance. Betel leaf contains 30\% phenol, the mechanism of phenol as an antibacterial agent acts as a toxinand can cause damage to bacterial cells, activate enzymes and cause damage to bacterial cells, activate enzymes and cause bacteria to die (Suparni, 2012), mainly onbacteria Escherichia coli dan Staphylococcus Aureus( Nurlman,2009), as well asblack pigmented bacteria (Wijaya, Maharani, Gunawan \& Puspitawati, 2017).

Binahong plants or AnrederaCordifolia are potential medicinal plants that can overcome this type of disease, and very suitable for healing perineal wounds in the post partum(Wijayanti, Heni \& Esti, 2017). This plant comes from the plains of China with its original name is Dhengshan chi, known as Maderia Vine.

\section{MATERIALS AND METHODS}

The research method used in this study is pre-experiment design with one group pretest and post-test design approaches. The population of all young women who experienced fluor albus was 34 in January to February 2019 and a large sample of 25 children with consecutive sampling technique. Then tabulated, analyzed using the Wilcoxon Sign Rank Test.

\section{RESULTS}

In this study the majority of respondents were Student age (68\%), Frequency of changing underpants (88\%), Frequency Drying Pubic Area (76\%), No Using Pantylinear (88\%)and Frequency of Not Changing Pantylinear at least 3 hours (88\%). Thedistribution results are in table 1.

Table 1 Distribution of respondents based on the characteristics of Student age, Frequency of changing underpants, Frequency Drying Pubic Area, Using Pantylinearand Frequency of Changing Pantylinear at least 3 hours.

\begin{tabular}{lcc}
\hline \multicolumn{1}{c}{ Variable } & Frequency & Percentage \\
\hline Student Age & 17 & 68 \\
$14-16$ & 8 & 32 \\
$17-20$ & & 88 \\
Frequency of changing underpants & 22 & 12 \\
Yes & 3 &
\end{tabular}




$\begin{array}{lcc}\text { Yes } & 19 & 76 \\ \text { No } & 6 & 24 \\ \text { Using Pantylinear } & 3 & 12 \\ \text { Yes } & 22 & 88 \\ \text { No } & & \\ \text { Frequency of Changing Pantylinear at least 3 hours } & 8 & 32 \\ \text { Yes } & 17 & 68 \\ \text { No } & 17\end{array}$

Table 2 Distribution of respondents based on the before and afterbeing given a binahong leaf decoction

\begin{tabular}{ccccc}
\hline \multirow{2}{*}{ Leucorrhoea healing } & \multicolumn{2}{c}{ Before } & \multicolumn{2}{c}{ After } \\
\cline { 2 - 5 } & Frequency & $\%$ & Frequency & $\%$ \\
\hline Not cure & 25 & 100 & 1 & 4 \\
Recover less & 0 & 0 & 20 & 80 \\
Cured & 0 & 0 & 4 & 16 \\
\hline
\end{tabular}

Table 3 The Influence of Binahong (AnrederaOrdifolia) Leaf Decoction on the healing of Flour Albus

\begin{tabular}{ccccccccc}
\hline Post-test & \multicolumn{2}{c}{ Not recured } & \multicolumn{2}{c}{ Recover less } & \multicolumn{2}{c}{ Cured } & \multicolumn{2}{c}{ Total } \\
\cline { 2 - 9 } Pre-test & $\Sigma$ & $\%$ & $\Sigma$ & $\%$ & $\Sigma$ & $\%$ & $\Sigma$ & $\%$ \\
\hline Not cured & 1 & 4,0 & 20,0 & 80,0 & 4 & 16 & 25 & 100 \\
Recover less & 0 & 0 & 0 & 0 & 0 & 0 & 0 & 0 \\
Cured & 0 & 0 & 0 & 0 & 0 & 0 & 0 & 0 \\
\hline Total & 1 & 4,0 & 20 & 80,0 & 4 & 16,0 & 25 & 100 \\
\hline
\end{tabular}

In table 3 above it can be explained that before being given a binahong leaf decoction all had fluor albus as much as $25(100 \%)$, but after being given a decoction of binahong leaves almost all fluor albus was reduced after being given a binahong leaf decoction of $20(80 \%)$ and a small portion of fluor albus was not recovered after being given a decoction of binahong leaves as much as $1(4 \%)$. The results of the Wilcoxon Sign Rank Test analysis using the SPSS PC for windows version 22.0 program on the effect of the decoction of Binahong leaves (AnrederaCordifolia) on the healing flourAlbuson female students of class XI SMAN 1 Paciran, LamonganDistrict can be seen that the value of $Z=-4,613 \mathrm{bd}$ and $p$ sign $=0,000$. because $p<\alpha, H 1$ is accepted, which means that there is an influence of the decoction of leaves of Binahong (AnrederaCordifolia) on healing flourAlbuson female studentsofclass XISMAN 1 Paciran, Lamongan District in 2019.

\section{DISCUSSION}

Before the Binahong Leaf Stew is Given In table 2 it can be explained that before using herbal ingredients namely decoction of leaves of Binahong (AnrederaCordifolia), all 25 $(100 \%)$ adolescents experience fluor albus. This can occur because in adolescents there are many changes, both physical changes. Krummel said that adolescence is a period of growth and process of human maturity, during this time a very unique and sustainable change occurred. Physical growth in adolescents occurs simultaneously with the maturing process of reproductive organs (Badriah, D, 2011).

According to Soekidjo (2009) in the medical journal Meliza R, et al (2012) factors that influence fluor albus one of which is age, the younger a person's age will affect the level of knowledge and how to maintain the cleanliness of genetal organs especially genetal regions. This is closely related to the age of the respondents listed in table 1 , it can be explained that more than a portion of young female students aged 14-16 years were 17 $(68 \%)$ and a small portion were $8(32 \%)$.According to the theory explained according to Sarwono (2011) and Hurlock (2011) Middle Adolescence (Middle Adolescence) middle adolescents often like friends who have traits similar to themselves, but also are in a state of confusion because they still don't know which one to choose. , such as sensitive or uncaring, busy or alone, optimistic or pessimistic.

Late adolescents late adolescents tend to make friends with other people in their search for new experiences and their higher interest in higher power or thought processes related to knowledge. Late adolescents already have a lot of experience and knowledge gained, and have high thinking power, so that late adolescents 
already know how to take good actions in preventing fluor albus, including in protecting and caring for their female area. Intermediate adolescents and late adolescents both have health risks to their reproductive organs to be affected by pathological fluor albus, so good action is needed in caring for or protecting the female area.

In adolescents, the cause of fluor albus is the behavior of preventing fluor albus that is not good, namely bad hygene after urinating and defecating, causing pathogens to contaminate the vulva, inadequate hand washing can irritate or be contaminated with bacteria on the vulva, tight clothing, underwear not absorbing can also cause irritation (Mokodongan, 2015). In table 1 the results for the frequency of changing underpants are almost all teenage girls who frequently change underpants at least $2 x$ a day are as many as 22 $(88 \%)$ and a small proportion of female students who do not change underpants less than $2 x$ a day are as many as $3(12 \%)$, so many female students who do personal hygiene properly, by doing the habit of changing underwear regularly can prevent the emergence of fungus and bacteria.

Table 1 explains the results related to the frequency of drying the pubic area, which is that almost all teenage girls often dry the pubic area after BAK / BAB is as much as $19(76 \%)$ and a small proportion of female students who do not dry the pubic area after BAK / BAB is as much as $6(24 \%)$ thus many female students who drain the pubic area after BAK / BAB. Next is the use of pantyliners, in table 1 it is explained that almost all female students who do not use pantylinear are $22(88 \%)$ and a small proportion of female students who use pantylinear are 3 $(12 \%)$. In table 1 related to the frequency of changing pantylinear, based on the above table it can be explained that more than a portion of female students who do not frequently change pantylinear at least 3 hours every $2(67 \%)$ and almost a majority of young girls often change pantylinear at least 3 hours as much as 1 ( $33 \%$ ). So it can be concluded that some female students still pay attention to their cleanliness well, it can support the process of healing fluor albus.

Another thing that can cause fluor albus is physical and psychological factors, namely stress, fatigue and also the factor of the underwear material that cannot absorb sweat, the use of tight pants can also cause high humidity in the pubic area so that growing fungus can cause itching in the genitals. This is supported by the theory according to Ayuningsih (2010), namely unhygienic behavior, stress so that the immune system is low, vaginal discharge due to fatigue can occur due to germs that cause infections that cause acidity in the area around the vagina is disturbed. While the theory according to EnyKusmiran (2011) is a cause of fluor albus including the use of antibiotics for too long, malnutrition, contraception, tight underwear, contraception, and hygiene factors. So it can be concluded that fluor albus can occur due to unhygienic behavior patterns in young women if left unchecked can cause itching and unpleasant odors due to the emergence of bacteria and fungi in the vaginal area. Leucorrhoea Recovery AfterBinahong Leaf Decoction

In table 2 above shows that almost all fluor albus girls are reduced after being given a binahong leaf decoction that is as much as 20 $(80 \%)$ and a small proportion of fluor albus girls do not recover after being given a binahong leaf decoction that is $1(4 \%)$. This can occur because personal hygiene should be assisted by using herbal ingredients in the form of a decoction of binahong leaves. This opinion is supported by research from the Nursing Journal Notokusumo (2016) that can be done to reduce the occurrence of fluor albus including pharmacologically (drugs from doctors), nonpharmacology such as changes in behavior, personal hygiene, psychology, and consuming herbal products that are believed to be useful. . So from the results of the study above show that the success of Binahong leaf decoction on the healing of flor albus in female students almost entirely experienced a change from not recovering to diminishing or even recovering. Thus it shows that after being given herbs in the form of a decoction of binahong leaves for 5 days can increase healing in fluor albus.

This is supported by research results that binahong (Anredera cordifolia) is commonly used to treat living organism (Basyuni, Yulianti, Br \& Lesmana, 2017), selain itu sebagai anti inflamasi (Laksmitawati, D.R, et al, 2017).Binahong leaf decoction can be used to maintain intimate hygiene, the presence of flavonoids contained in Binahong leaves is as an anti-oxidant. This is also supported by the theory according to (Susetya, Darma, 2015),binahong has flavonoid content, pharmacological activation of flavonoids is as anti-inflammatory, analgesic, anti-oxidant. Flavonoids are said to be natural anti-oxidants because they can capture free radicals by freeing hydrogen atoms from their hydroxyl groups. How it works from the content of flavonoids in binahong leaves is to inhibit the onset of infection in the body by capturing free radicals in the body. 
The Influence of Binahong
(AnrederaCordifolia) Decoction on FlourAlbuson Female Students of Class XI SMAN 1 Paciran, LamonganDistrict in 2019.

In table 3 above, the results of the study of healing of fluor albus before being given a binahong leaf decoction are all or all female sudents experiencing fluor albus as much as 25 $(100 \%)$, whereas healing of fluor albus after being given a binahong leaf decoction shows that almost all female fluor albus is reduced after a leaf decoction is given Binahong is 20 $(80 \%)$ and a small proportion of fluor albus girls do not recover after being given a binahong leaf decoction that is $1(4 \%)$.

The results of the Wilcoxon Sign Rank Test analysis using the SPSS PC for windows version 22.0 program on the Effect of Binahong Leaf Decoction (AnrederaCordifolia) on Healing Flour Albuson female students of Class XI SMAN 1 Paciran, LamonganDistrict in 2019, it can be seen that $Z$ value $=-4,613 b$ and significant value $(p$ sign $=0,000)$. Where the probability value and significance value $p$ $<0.05$, then $\mathrm{H} 1$ is accepted, which means that there is the Influence of Binahong Leaf Decoction (AnrederaCordifolia) on Healing Flour Albuson female students of Class XI SMAN 1 Paciran, Lamongan District in 2019.

This is because by using herbal ingredients Binahong leaf decoction can reduce fluor albus and even heal if it can be patient through the processes that have been determined, and assisted with a clean environment and personal hygiene. So it can be said that using this binahong leaf decoction can reduce the severity of fluor albus in general. This opinion is supported by previous research conducted by Hermila (2011) in the medical journal NanikSulistyani, et al (2011) said that $70 \%$ ethanol extract of binahong leaves (AnrederaCordifolia) has activity as an antifungal against C.albicans with Minimum Kill Rate (KBM) as much as $42 \%$. The extract contained alkaloids, polyphenols, flavonoids, and saponins based on the results of test tubes and thin layer chromatography. This is also in line with research byPuspita, $\mathrm{R}$, at el (2016) at Al IzzahDemak Islamic Boarding School which states that it means that there is a effect of a worm with boiled water of binahong leaves to prevent fluor albus in adolescents.

Fluor albus healing is also supported by good personal hygiene behavior, in addition to good personal hygiene, physical and psychological conditions that are not good can also cause fluor albus in adolescents, such as hormonal changes, stress, fatigue and so forth. Opinion above is supported by the theory according to Fadilla, et al (2012) in the medical journal Abrori, et al (2017) says that the cause of fluor albus in addition to infection with microorganisms such as bacteria, fungi, viruses, parasites. Also caused by disorders of hormonal balance, stress, chronic fatigue, genital inflammation, foreign bodies in the vagina, and there are diseases in the reproductive organs such as cervical cancer.

Adolescence is puberty, puberty where the hormone estrogren and progesterone increase in this period so that it can increase acid levels in the body and can also increase the productivity of sweat in the body, if the cleanliness of the body is not maintained properly then arises fluor albus, but by using decoction of leaves Binahong can reduce and even cure fluor albus.

Based on research conducted by researchers with the title research on the effect of binahong leaf decoction (AnrederaCordifoia) on healing Flour Albus in adolescents, shows that binahong leaf decoction is used as an alternative way to reduce the severity of leucorrhoea due to containing leaf binahong flavonoids as anti-oxidants against free radicals. Thus binahong leaf stew can cure fluor albuson female students of class XI SMAN 1 Paciran Lamongan District.

\section{CONCLUSION}

There is an influence of decoction of leaves of binahong (anrederacordifolia) on the healing flour albuson female students of class XI SMAN 1 Paciran, LamonganDistrict in 2019. From the results of this study are expected to contribute to science, especially in terms of therapy, the level of fluor albus and as a source of comparison for the world of science in producing information about providing therapeutic treatment to female students who experience fluor albus.Further research needs to be carried out on other factors that have to do with the influence of Binahong leaves (AnrederaCordifolia) on healing Flour Albus, and it is hoped that the results of this study will increase knowledge in studying the effect of Binahong leaves (AnrederaCordifolia) on the healing of Flour Albus in female students.

\section{REFERENCES}

Anurogo, D. \& Wulandari, A,2011,Cara Jitu Mengatasi Nyeri Haid, Edisi 1,Yogyakarta, ANDI.

Ayuningsih, F.,Teviningrum,S.,Krisnawati, I, 2010, Cara holistic danpraktisatasiGangguanKhasPadaKe sehatanWanita, Jakarta, 
Badriah,

2011, GiziDalamKesehatanReproduksi, Bandung, PTRefikaAditama.

Basyuni, M., Yulianti, P., Br, A., \& Lesmana I, 2017, Phytochemical Analysis of Binahong (Anredera Cordifolia) Leaves Extract to Inhibit In Vitro Growth of Aeromonas Hydrophila, AIP Conference Proceedings 1904, 020072.https://doi.org/10.1063/1.5011 929.

Depkes

DataPendudukSasaranProgam

2011,

Pembangunan Kesehatan. Available

http:/www.depkes.go.id/

download/publikasi/Data

PendudukSasaranProgam.Accessed.

October 2018

Fadillah, dkk, 2012, "Faktor Yang BerhubunganDenganKejadianKeputih anPatologisSiswi SMAN 1 SIMPANG HILIR KabupatenKayong Utara", JurnalKesehatanAbrori,

$d k k$,Diaksespadatanggal 22 April 2019.

Hermila,

2011,"AktivasiAntifungiEkstrakEtanolB atangBinahong (AnrederaCordifolia) terhadap Candida Albicans Serta SkriningFitokimia", JurnalKesehatanNa nikSulistyani,

$d k k$,Diaksespadatamggal 22 April 2019.

Kusmiran,

E,2011,KesehatanReprodusiRemajad anWanita. Jakarta,SalembaMedika.

Laksmitawati, D.R., Widyastuti, A., Karami, N., Afifah, E., Rihibiha, D.D., Nufus, H., \& Widowati, W.(n.d), 2017, Antiinflammatory effects of Anredera Cordifolia and Piper Crocatum Extracts on lipopolysaccharide-stimulated macrophage cell line.A Journal of the Bangladesh Pharmacological Society (BDBS), 12, 35-40,https: doi.org/10.3329/bjp.v12il.28714.

Mokodongan, $\mathrm{MH}, 2015$, "Hubungan tingkat Pengetahuan Tentang Keputihan Dengan Perilaku Pencegahan Keputihan Pada Remaja Putri", Jurnal e-Clinic (eCl), Volume 3, Nomor 1.

Notokusumo, 2016,"Pengaruh Pemberian Agar-Agar Lidah Buaya TerhadapKejadianKeputihan", Jurnal Keperawatan Notokusumo, 6970,Diakses 23 September 2018.
Nurlman, M, 2009, "Aktifitas Anti BakteriEkstrakMetanolBungaPepayaJ antan (Carica Papaya L) TerhadapEscherichia coli dan Staphylococcus

AureusMultiresistenAntibiotik", Jurnalke sehatan,Diakses 23 September 2018.

Prijatni, ID, 2016, Kesehatan Reproduksi dan Keluarga Berencana, Jakarta, Modul Bahan Ajar Cetak Kebidanan.

Puspita R, Machmudah, Sayono, 2016, Cebok dengan Rebusan Air Daun Binahongdapat Mencegah Terjadinya Keputuhan Patologispada Remaja di Pondok Pesantren Al-Izzah Demak, ejournal STIKES TelogorejoSemarang. Diakses 23 September 2018.

Sarwono, SW, 2013,Psikologi Remaja Edisi Revisi, Jakarta, Rajawali Pers.

Soekidjo,

2009,"GambaranPerilakuRemajaPutri

MenjagaKebersihan Organ

GenetliaDalamMencegahKeputihan", $J$ urnalKesehatanMelizaRizky, dkk,Diaksestanggal 20 Mei 2019.

Suparni. (2012). Herbal Nusantara. Yogyakarta: Rapha publishing Susetya,D, Khasiat dan Manfaat Daun Ajaib Binahong, Yogyakarta, Baru Perss.

Susetya, D, 2012,Khasiat dan Manfaat Daun Ajaib Binahong,Cetakan 1, Yogyakarta, Baru Perss, p.25.

Wijaya, V., Maharani, E.S., Gunawan, H.A., \& Puspitawati, R.I.A, 2017, The Efficacy of an Infusion of Binahong Leaves (Andedera Cordifolia (Ten) Steenis) against wild strain black-pigmented bacteria. 9(2). International Journal of Applied Pharmaceutics, Vol 9, Special Issue 2. ISSN 0975-7058.

Wijayanti, K., Heni, R., \& Esti, S, 2017,Effectiveness of Binahong Decogtion Water (Anredera Cordifolia (Ten) Steenis) for Perineal Wound Healing at Home DeliveryAesya Grabag Magelang, Indonesia. International Journal of Research in Medical Sciences. May, 5(5), 1970-1975. www.msjonline.org. DOI: http://dx.doi.org/10.18203/23206012.ijrms2017182. 